\title{
Inovace předmětu Angličtina pro cestovní ruch na Fakultě ekonomické Západočeské univerzity v Plzni
}

\author{
Petra Hromádková, Jitka Ramadanová
}

\begin{abstract}
Abstrakt: Příspěvek je věnován inovačnímu projektu VS-18-007 vnitřní soutěže ZČU, který byl realizován vyučujícími Ústavu jazykové přípravy v roce 2018. Autorky příspěvku si kladou za cíl seznámit nejen podobně specializované kolegy působící v oblasti jazykového vzdělávání, ale i širší odbornou veřejnost s obsahem a postupy tohoto projektu a především sdílet zkušenosti z následné aplikace výstupů projektu ve výuce. Cílem projektu byla inovace předmětu Angličtina pro cestovní ruch s využitím modernějších výukových materiálů a také i didakticky vhodnějších výukových a hodnotících metod, které by měly přispět k všestrannému jazykovému rozvoji studentů. Úvodní část př́íspěvku je věnována nové sadě učebních materiálů, obsahu a cílům inovovaného předmětu. Následně jsou zde uvedeny nově zvolené výukové a hodnotící metody i s jejich praktickými př́klady. Závěrem je v příspěvku popsáno také dotazníkové šetření, které bylo provedeno u studentů inovovaného předmětu po prvním semestru výuky a které bylo zaměřeno na hodnocení aplikace nových učebních materiálů a výukových a hodnotících metod ve výuce.
\end{abstract}

Klíčová slova: angličtina pro cestovní ruch, inovace, hodnocení, prezentace projektů, studentské portfolio, testy, výukové metody

Abstract: This paper deals with the innovation project VS-18-007 carried out by the teachers of the Institute of Applied Language Studies at the University of West Bohemia in Pilsen in 2018. The aim of the authors is to present both their colleagues teaching Business English at the institutions of higher education and other language teachers with the content and progress of the project, as well as to share their experience applying the results of the project to their teaching. The main goal of the project was to innovate the Course of English for Tourism by means of introducing more up-to-date teaching materials together with more efficient teaching and evaluation methods, which should contribute to enhanced language progress on the part of the students. Apart from the new set of teaching materials, the introductory part of the paper looks at the content and aims of the innovated course. The next part of the paper presents the newly adopted teaching and evaluation methods with some practical examples. Finally, the paper describes the type of the questionnaire given to students after the first term of teaching the innovated course. The questionnaire focused on the assessment of the use of new study materials and also the teaching and evaluation methods as part of the instruction process.

Key words: English for tourism, evaluation, innovation, presentations on specific projects, student portfolio, teaching methods, tests

\section{Úvod}

Projekt vnitřní soutěže VS-18-007 na ZČU v Plzni, schválený pod názvem Inovace předmětu Angličtina pro cestovní ruch ve studijních programech Fakulty ekono- 
mické, probíhal na UJP v době od 1.4. 2018 do 31.12. 2018. Stanoveným cílem projektu bylo inovování stávajícího předmětu UJP/EFT za pomoci nových učebních materiálů a výukových metod. Členové řešitelského týmu si pro naplnění cíle projektu vytýčili několik dílčích kroků, kterými posléze postupovali. Po získání finančních prostředků na nákup nových studijních materiálů bylo po úvaze rozhodnuto zakoupit učebnice Oxford English for Careers: Tourism 2 a také Oxford English for Careers: Tourism 3. Jde o dvě na sebe navazující učebnice od úrovně B1+ po úroveň C1 dle SERR. Následně po získání nových učebnic byl vypracován podrobný týdenní plán výuky pro daný předmět. Dalšími kroky bylo vytvoření elektronické opory v Courseware spolu se zadáním povinných semestrálních projektů s pravidly pro jejich hodnocení a př́prava sady testů pro průběžné a závěrečné testování znalostí a dovedností studentů podle nových, předem stanovených kritérií vycházejících $\mathrm{z}$ obsahu nově zavedených studijních materiálů. Uvedený předmět tak byl připraven v plné verzi pro nový akademický rok 2018/2019.

\section{Nová sada učebnic Oxford English for Careers: Tourism 2, 3}

Tato nová sada učebních materiálů, zaměřených na cestovní ruch nahradila dříve používanou učebnici English for International Tourism (Jacob, Strutt). Porovnáme-li výukový plán kurzu, který vychází z obsahu původní učebnice s výukovým plánem založeným na novém učebním materiálu, zjistíme, že jsou nové učebnice nejenom mnohem více zaměřeny na praktickou komunikaci $\mathrm{v}$ reálných situacích $\mathrm{v}$ oblasti cestovního ruchu, ale že obsahují i řadu v současné době velmi aktuálních témat, jako je např́klad udržitelný rozvoj cestovního ruchu, venkovský cestovní ruch, sociální cestovní ruch či rychle se rozvíjející specializovaný cestovní ruch (niche tourism), která vycházejí vstř́íc rozmanitým individuálním potřebám klientů. Uvedený studijní materiál je vhodný zejména pro studenty, kteří se v budoucnu chtějí věnovat pracovní kariéře $v$ oblasti cestovního ruchu, at' již ve sfére administrativní nebo manažerské.

\section{Obsah a cíle předmětu}

Předmět Angličtina pro cestovní ruch byl z hlediska obsahu inovován s cílem splnit anglické jazykové potřeby studentů cestovního ruchu a umožnit jim rozvíjet jazykové povědomí v oblasti cestovního ruchu, získat odbornou terminologii $\mathrm{z}$ oblasti cestovního ruchu, vybudovat důvěru v odborné dovednosti potřebné pro odvětví cestovního ruchu a procvičovat dovednosti v reálných situacích, které odrážejí aktuální otázky cestovního ruchu.

Předmět je určen studentům s jazykovou kompetencí na úrovni B2 dle SERR. Po jeho absolvování by měli studenti získat např́íklad odborné jazykové znalosti rozlišovat jednotlivé typy delegátů a průvodců $\mathrm{v}$ cestovním ruchu $\mathrm{v}$ různých destinacích, rozlišit různé druhy specializovaného cestovního ruchu a základní 
odborné termíny v nich používané apod. Dále studenti získají důležité odborné jazykové dovednosti, jako např́klad připravit a prezentovat komentář průvodce $\mathrm{v}$ cestovním ruchu $\mathrm{k}$ určité památce či lokalitě, připravit a prezentovat program úzce specializovaného zájezdu apod.

Jak již bylo uvedeno, $v$ inovovaném předmětu byla pro studenty též vytvořena elektronická podpora na Courseware. Její součástí jsou mimo jiné např́ílad doplňkové studijní materiály ve formě tematických článků, videí apod., které mají za cíl obsah předmětu zpestřit a jazykové znalosti a dovednosti studentů ještě více prohloubit.

Jako příklad jsou uvedeny zmíněné doplňkové studijní materiály pro první týdny kurzu, tak jak jsou pro studenty $k$ dispozici na Courseware:

Introduction to Tourism

http://www.prm.nau.edu/prm300/what-is-tourism-lesson.htm

Video - Introduction to Tourism

https://www.youtube.com/watch?v=a2uMKG7ETyQ

Video - Tour guide / Tour manager

https://www.youtube.com/watch?v=YhJk00gaBrk

Steps to creating great travel packages

https://www.tourismtribe.com/6-steps-to-creating-great-travel-packages/

V rámci elektronické podpory na Courseware byly pro studenty též vytvořeny semestrální projekty korespondující s jednotlivými týdenními tématy výuky. $\mathrm{Na}$ těchto projektech studenti během semestru pracují ve 3členných týmech. Vítány jsou též projekty, jejichž adekvátní a relevantní zadání si vymyslí sami studenti. Po dostatečně provedeném zpracování projektu je jednotlivé týmy následně ve výuce prezentují ostatním studentům.

Jako př́ílad je uvedeno jedno ze zadání semestrálního projektu, jedná se o téma Sustainable Tourism:

You are representatives of an eco-friendly tour operator in Prague. Create a set of guidelines for tourists that could assist them in planning the most sustainable and responsible trip to Prague. The guidelines should concern at least the following issues - transport, accommodation, souvenirs, activities. Search the Prague area for green organizations and initiatives working in this sector, examine their websites and support each of the guidelines with practical tips and examples. 
Je nutné též zmínit, že zadání jednotlivých projektů byla tvořena tak, aby měla pro studenty z hlediska jejich budoucího pracovního uplatnění v oblasti cestovního ruchu co nejpraktičtější přínos.

\section{Výukové metody}

Inovace předmětu Angličtina pro cestovní ruch proběhla nejen ve formě modernizace jeho obsahu a výukových materiálů, ale úzce $s$ tím souvisela též neméně důležitá část, a to použití modernějších didaktických přístupů a výukových metod.

Úloha vyučujícího není pouhé předávání odborných informací studentům, přestože to má svoji neodmyslitelnou důležitost. Úloha vyučujícího je především podněcovat zájem a zvídavost studentů o daný předmět, podněcovat jejich kreativitu a v procesu učení je povzbuzovat a vést (Robinson, 2016). Jedním z užitečných a nezbytných nástrojů vyučujícího jak tohoto dosáhnout je volba výukových metod. Výuka inovovaného předmětu je připravena tak, aby nabízela studentům rozmanité a prakticky zaměřené aktivity. To přispívá $\mathrm{k}$ tomu, aby byli studenti smysluplně zapojeni do školní práce, aby se zlepšil jejich vztah k předmětu, aby byli lépe motivováni a v neposlední řadě i lépe připraveni na svoji profesní dráhu.

Kromě těchto pozitiv má pestrost výukových metod vliv také na dobré třídní klima. Dobrá didaktika bezesporu přispívá k lepšímu vztahu mezi studenty a vyučujícím. Důležitým faktorem, který též pozitivně působí na klima ve tř́dě je spoluúčast studentů na výuce, tedy to, na čem se mohou podílet, o čem při výuce mohou rozhodovat apod. Výuka inovovaného předmětu je připravována tak, aby ve většině hodin měla vyučující $\mathrm{k}$ dispozici o jednu či dvě aktivity více a tedy i možnost dát studentům během hodiny na výběr podle jejich vlastního zájmu.

Zde je uvedena jako př́klad výuková aktivita z týdne, kdy bylo tématem turistický průvodce a tvorba zájezdu - On Tour. Protože se jedná o jazykovou výuku, volí vyučující hlavně aktivity, při kterých mají studenti možnost procvičit všechny čtyři jazykové dovednosti zároveň, tedy listening, reading, speaking, writing:

\section{Aktivita - Cestovní kancelář}

Libreto: Pro účely této aktivity studenti vytvoří dvoučlenné týmy a stanou se zástupci jimi zvolené cestovní kanceláře. Každý tým si zvolí název cestovní kanceláře, již existující nebo si vymyslí jméno zcela nové, a z lepících štítků si vytvoří jmenovku s názvem cestovní kanceláře, kterou reprezentují.

Týmy mají $\mathrm{k}$ dispozici arch papíru o velikosti $\mathrm{A} 3$ a několik barevných fixů. $\mathrm{V}$ rámci přípravy na hodinu byla vyučující vytvořena sada kratších textů, kde každý z nich nabízí informace o jedné turistické destinaci - atraktivní místa v rámci této destinace a zajímavé informace o nich. Každý tým má možnost volby jedné z uvedených 
destinací dle vlastního zájmu. Úkolem každého týmu je vytvořit výukový plakát neboli stránku do katalogu jejich cestovní kanceláře obsahující trasu zájezdu po zvolené destinaci s jednotlivými místy včetně zajímavých informací o nich, a to tak, aby byl plakát co nejatraktivnější pro klienty jejich cestovní kanceláře. Jako zdroj informací používají týmy texty, které obdržely od vyučující, plus by měly získat rozšiřující informace alespoň o jednom z míst z online zdrojů. Časový fond pro tuto část aktivity je přibližně 30 minut.

Poté, co týmy dokončí tvorbu svého zájezdu, zavěsí své plakáty na stěnu kolem obvodu tř́dy a každý tým postupně svůj zájezd krátce prezentuje ostatním studentům, tj. potenciálním klientům své cestovní kanceláře. Časový fond pro tuto část aktivity je 15-20 minut.

Poslední částí této aktivity je část zvaná galerie. Každý z týmu se projde po obvodu tř́dy a prohlédne si zblízka a podrobně plakáty všech ostatních týmů. Úkolem každého týmu je nyní na základě předchozích prezentací a podrobnou prohlídkou všech plakátů vybrat tu cestovní kancelář, pro jejíž zájezd by se jako klienti rozhodli, a své rozhodnutí zdůvodnit. Časový fond pro tuto část aktivity je 10-15 minut.

Jako příklad jsou uvedeny ukázky dvou výukových plakátů studentů z letního semestru školního roku 2018/2019 (obr. 1).

V souvislosti s rozmanitostí výukových metod a modernizací výuky v rámci inovovaného předmětu je také nutné alespoň okrajově zmínit využití technologií při výuce. Ty zajisté nejsou v uvedeném kurzu hlavním nástrojem výuky, ale jsou vhodným doplňkem, který zábavnou formou obohacuje pestrost používaných aktivit. Jedním z příkladů je aplikace Plickers, jíž je možné v hodinách využít formou zábavných kvízů k opakování probraných témat. Předem připravené otázky promítá vyučující na interaktivní tabuli a studenti pomocí kartiček připomínajících QR kódy vybírají správné odpovědi. Statistika jednotlivých odpovědí se okamžitě zobrazuje na tabuli. K podobným účelům lze využít také aplikaci Kahoot! Jejím prostřednictvím promítá vyučující otázky na interaktivní tabuli a studenti provádějí volbu správné odpovědi pomocí barevných obrazců na svých mobilních telefonech.

Dalším př́íkladem použití technologií v inovovaném kurzu je aplikace Clarisketch. Tato aplikace je jednoduchým nástrojem pro tvorbu komentovaných videí. Jednoduše zakreslujete detaily do vámi vybrané fotografie či vlastní kresby a Clarisketch zároveň nahrává váš hlasový komentář. Poté stačí video jen jednoduše sdílet. Studenti měli za úkol vytvořit krátké výukové video, ve kterém vysvětlí ostatním studentům libovolně zvolené téma. Tato aktivita přinesla mnoho povedených výtvorů na zajímavá a prakticky zaměřená témata, např́íklad Plan an expedition, Guided commentary apod., která jsou pro studenty z hlediska jejich budoucího pracovního uplatnění v oblasti cestovního ruchu jistě př́nosem. 

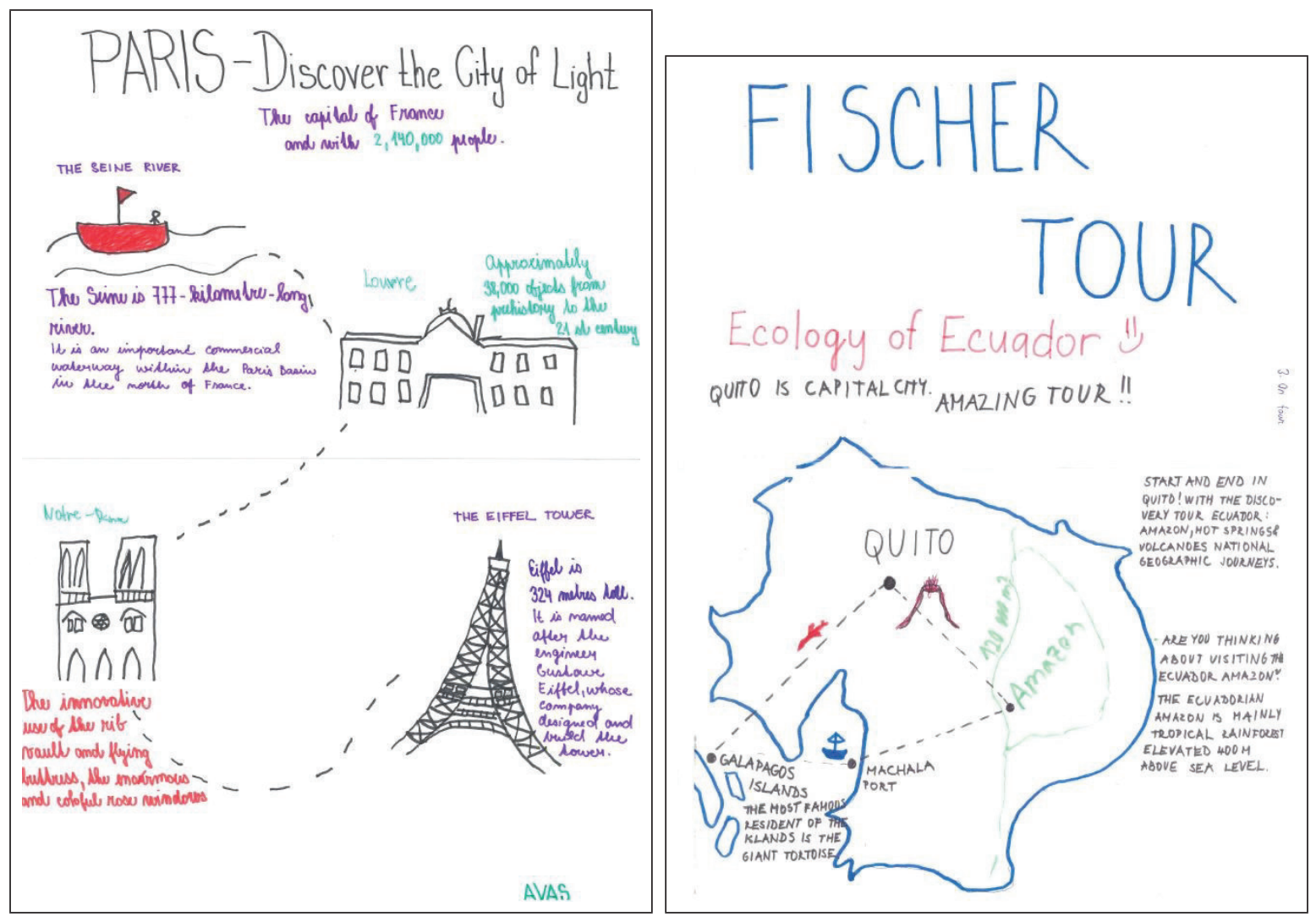

Obr. 1: Ukázky výukových plakátů

\section{Hodnocení}

Hodnocení je jedním z klíčových faktorů při práci vyučujícího ve třídě a ovlivňuje i další aspekty týkající se samotného předmětu, jako je například třídní klima, vztah studentů $\mathrm{k}$ předmětu či vztah k vyučujícímu. Prostřednictvím hodnocení získává vyučující nejen přehled o jazykové úrovni dosažené studenty, ale získává také určitou představu o kvalitě své práce. $Z$ tohoto důvodu se inovace předmětu Angličtina pro cestovní ruch týkala i používaných hodnotících metod.

V inovovaném předmětu se nepoužívá nebo alespoň minimalizuje normativní hodnocení, to znamená, že vyučující nesrovnává studenty mezi sebou, ani jejich výkony. Z jejich výkonů nedělá žebříček pomocí bodů, procent, známek apod. Raději se přiklání k hodnocení podporujícímu, suportivnímu (Čapek, 2017). Používá hodnocení, které v sobě obsahuje posílení pocitu dobře vykonané práce, hodnocení s individuálním přístupem, kdy srovnává aktuální výkony studenta s jeho minulými výkony a hodnotí je tak hlavně z hlediska vývoje.

Jedním z požadavků inovovaného předmětu pro udělení zápočtu je aktivní účast studentů na hodinách a plnění zadaných úkolů. Co se týče hodnocení těchto jednotlivých úkolů/aktivit, nejsou studenti, jak již bylo řečeno, srovnáváni s ostatními 
studenty či se stoprocentním a perfektním výkonem, pouze se zadaným úkolem je-li splněn či ne. Vyučující hodnotí dobrou práci studentů neboli celkový proces vedoucí ke splnění aktivity, a to na základě předem pečlivě stanovených kritérií.

Jako příklad jsou uvedena kritéria k výše popsané aktivitě - Cestovní kancelár̆. Pokud tým takto stanovená kritéria dodrží, je jejich úkol hodnocen pozitivně jako splněn, bez ohledu na kvalitu výsledků ostatních týmů a porovnávání s nimi:

With your team partner,

- Agree on the tour operator/travel agency you will represent,

- Choose one of the popular destinations offered and study the particular text about the destination,

- Based on the information, create a new tour in the destination and corresponding poster/catalogue page introducing your new tour,

- For the different places of your tour, use the information from the text, and for one of them, search for some extra information online,

- Complete the task on time, do not exceed the time limit of 30 minutes,

- In about 5 minutes, present your tour to the rest of the class / your potential customers.

Potvrdilo se nám, že tato forma hodnocení poskytuje příležitost zažít úspěch i těm studentům, kteří při normativním hodnocení příliš nevynikají a které formativní hodnocení pasovalo ve třídě do role outsiderů. Jestliže se jim touto cestou dostane ocenění, jistě to zvyšuje jejich motivaci $\mathrm{k}$ učení a zlepšuje celkový vztah $\mathrm{k}$ předmětu.

\section{Portfolia}

Jedním z hodnotících nástrojů, které byly v rámci inovace předmětu Angličtina pro cestovní ruch též nově zavedeny, je tzv. studentské portfolio, jenž je pro studenty zároveň určitou formou samostudia. V tomto významu slova portfolio se jedná o soubor týdenních prací, které si každý student vytváří mimo výuku během semestru do svého pořadače k průběžnému i konečnému hodnocení. Pro hodnocení portfolií jsou předem pevně stanovena kritéria, se kterými jsou studenti hned na začátku semestru seznámeni.

Každý týden vkládají studenti do portfolií na základě probíraných témat své týdenní př́íspěvky ve stanoveném rozsahu alespoň jedné strany A4, kde každé jednotlivé téma doma zpracovávají a rozšiřují o informace získané vlastním sběrem $\mathrm{z}$ různých zdrojů a jejich samostudiem. $\mathrm{V}$ případě, že by některé $\mathrm{z}$ témat považoval student za př́liš nezajímavé, může mu být dána možnost toto téma nahradit svým vlastním příspěvkem, například popisem obsahu a hodnocením knížky, kterou četl 
v angličtině, nebo filmu, který též zhlédl v angličtině apod. Někdy si může student zase zahrnout do svého portfolia povedený výtvor vytvořený prrímo ve výuce (výukový plakát, pracovní list, tematický projekt apod.).

Jedním z účelů tvorby studentských portfolií je nejen upevnění a prohloubení znalosti probíraných témat, ale také demonstrace toho, že se každý ze studentů angličtině během semestru průběžně věnuje i mimo čtyři stěny učebny, jinými slovy, že angličtina tvoří určitou součást jejich běžného života. Potvrdilo se nám, že touto formou hodnocení se ocenění dostane i těm studentům, kteří v běžné výuce nevynikají. Výhody studentského portfolia jsou navíc umocněny tím, že napomáhá $\mathrm{k}$ tomu, aby studenti přebírali větší zodpovědnost za vlastní jazykové vzdělání, zvyšuje jejich motivaci $\mathrm{k}$ učení a podporuje jejich kreativitu.

Grafická stránka a forma zpracování portfolia je svobodnou volbou každého studenta. Pro představu je jako příklad uvedeno několik ukázek ze studentských portfolií z letního semestru školního roku 2018/2019 (obr. 2).

\section{Testy}

Testování je činnost, která si jistě zaslouží velkou pozornost. Většina studentů ji považuje za důležitou, protože na úspěšném zvládnutí testu často závisí také jejich úspěšné zakončení kurzu, proto je testování pro studenty často velmi stresující.

Test by měl být sestavován tak, aby neověřoval pouze znalosti studenta, tedy nižší úroveň myšlení, ale také jeho dovednosti a postoje. Především z tohoto důvodu byla pro účely inovovaného předmětu vytvořena sada testů tzv. tř́stupňových (Čapek, 2017). Tento typ testu byl sestaven ze tří druhů otázek. Jsou v něm otázky prvního stupně, tzn. otázky ověřující studentovy odborné znalosti daného tématu, dále otázky druhého stupně, tzn. otázky ověrující studentovy odborné dovednosti, a nakonec otázky třetího stupně, tzn. otázky týkající se jeho postoje $\mathrm{k}$ danému tématu, tedy ověřující vyšší úroveň myšlení.

Pro představu je zde jako př́klad uvedena část vzorového testu, který byl vytvořen pro účely inovovaného předmětu, kde otázka č. 1 je otázkou prvního stupně, otázka č. 2 je otázkou druhého stupně a otázka č. 3 je otázkou třetího stupně:

1. We talked about seven different types of holiday reps. Name at least three of them and describe at least three of his/her job duties. 

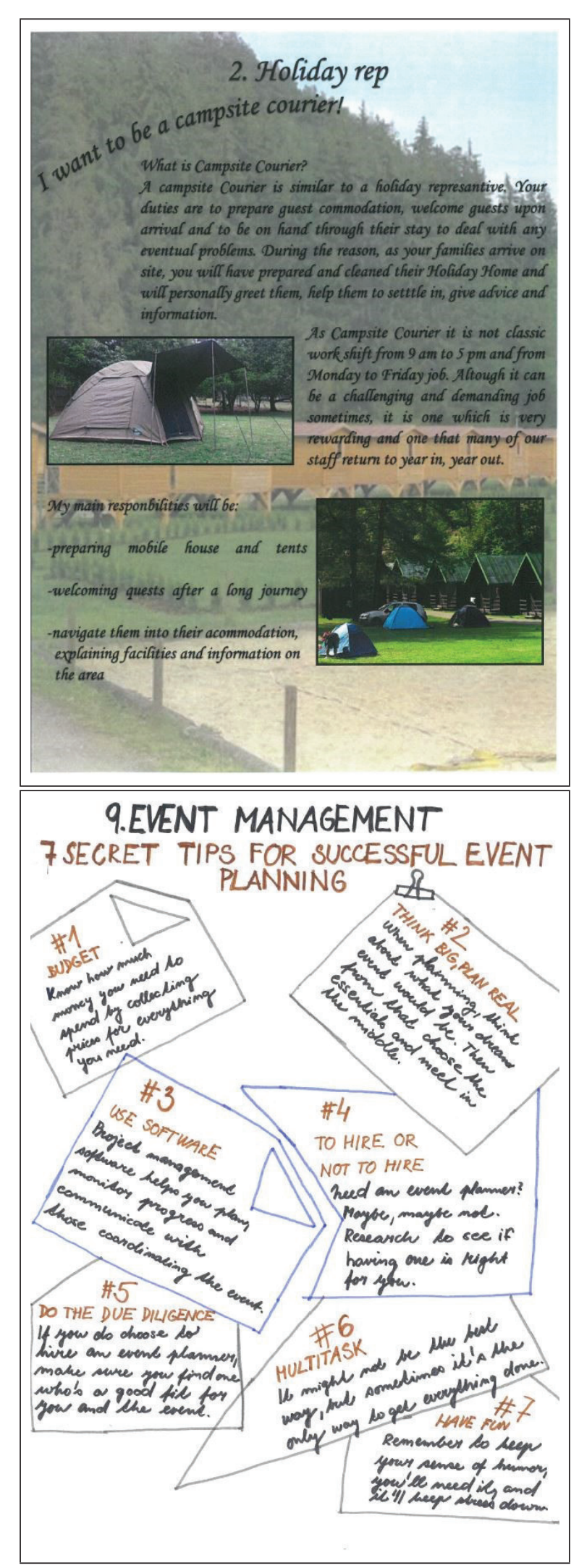

\section{Rural tourism}

Rural tourism focuses on actively participating in a nural lifestyle. It can be a variant of ecotourism. Many villages can facilitate tourism because many villagers are hospitable and eager to welcome (and sometime even host) visitors. I choose Ho66iton in New Zealand.

There are 44 underground ho66it houses with typical round doors. With a few exceptions, there is notfing befind the door, 6ut you still feel like you are in Middle-earth. The team of people keeps the gardens here and everything is done so that the vilfage really looks afive.

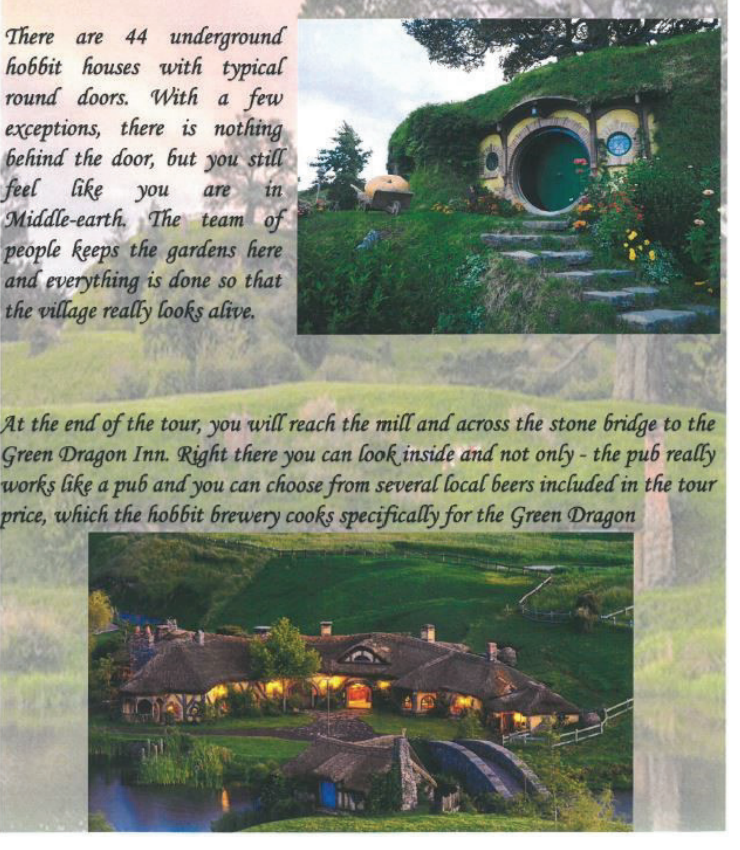

At the end of the tour, you will reach the mill and across the stone bridge to the Green Dragon Inn. Right there you can look inside and not only - the pub really works like a pub and you can choose from several local beers included in the tour price, which the hob6it brewery cooks specifically for the Green Dragon

10. SUSTAINABLE TOURISM

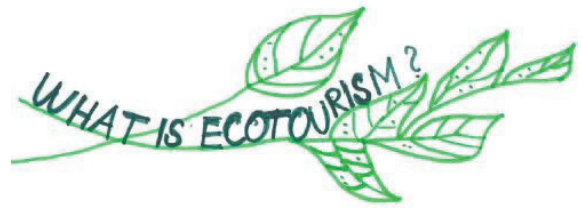

Ecolowriam (also called andaimable touriom) can be elefimed by a mariely of havel practices, lub it all comes dowm to a general sed of ideras. As an eco-lowrist, you decide to havel in a way that shows resped do mature and doeb mol conbributer do its degradation.

PRINCIPLES OF ECOTOURISM:

- Minimize physical, social, behavional and psychological

- Build environmental and cultunal awareness and respect - Provide positive experiences for both visitors and - Provide direct financial benefits for environmental - Generate financial benefits for both local peple and private industry

- Design,construct and pperate low-impact facilities

Obr. 2: Ukázky ze studentských portfolií 
2. Explain the differences between the job of a tour manager and a tour guide.

3. Specialized tourism offers plenty of different micro-niches. As a tourist, which of them do you find the most appealing and why?

Je nutné zde znovu zmínit, že testování představuje pro většinu studentů nemalý stres a tento typ hodnocení je jim pak překážkou v efektivním procesu učení. Písemné testy u tohoto typu kurzu ani nepředstavují příliš dobrou didaktiku. $\mathrm{Z}$ těchto důvodů jsou výše zmíněné testy $\mathrm{v}$ inovovaném předmětu používány pouze okrajově, tj. pouze $\mathrm{v}$ př́ípadě, že studenti nesplní některý $\mathrm{z}$ dalších požadavků udělení zápočtu - plnění zadaných úkolů ve výuce, prezentace semestrálního projektu a studentské portfolio. Každý z těchto tří požadavků, jak bylo již výše uvedeno, má svá předem stanovená kritéria, se kterými jsou studenti hned na začátku semestru seznámeni. V případě, že studenti některý z požadavků dle těchto kritérií nesplní, pak teprve následuje zmíněný třístupňový test.

Nutno dodat, že u typů testů, které se nesoustředí jen na pouhé reprodukování znalostí, ale též na ověřování dovedností a postojů studentů, se dle výsledků testování ukazuje, že se při něm snižuje celková neúspěšnost studentů (Čapek, 2017).

\section{Dotazníkové šetření}

Po ukončení výuky v zimním semestru akademického roku 2018/2019, kdy byl inovovaný předmět pilotován ve výuce, byla provedena jeho závěrečná evaluace formou dotazníkového šetření. Jednalo se především o evaluaci výstupů projektu, tj. nových učebních materiálů a zvolených výukových a hodnotících metod.

Pilotáž inovovaného předmětu proběhla paralelně ve třech skupinách studentů FEK, tj. celkem se 66 studenty, se kterými bylo následně provedeno dotazníkové šetření formou anonymního dotazníku. V předloženém dotazníku studenti hodnotili nově zvolenou sadu učebních materiálů, tj. obsah jednotlivých hodin, a také nově zavedené metody výuky a hodnocení. V zájmu návratnosti dotazníkového šetření, byla volena co nejjednodušší forma odpovědí.

V první části dotazníku byla studentům předložena škála všech probraných témat programu předmětu a studenti měli označit tři z těch, která je nejvíce bavila a mě- 
la pro ně, podle jejich názoru, z jazykového a odborného hlediska největší přínos. Výsledky tohoto šetření jsou uvedeny v grafu 1.

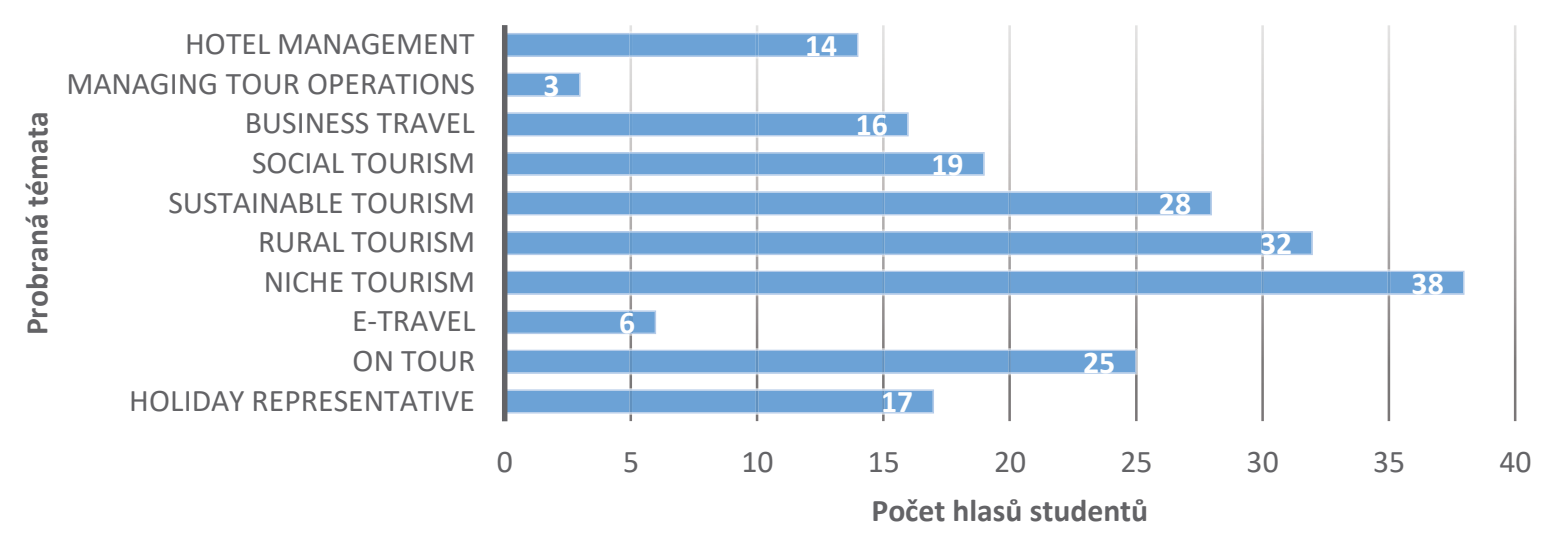

Graf 1: Graf oblíbenosti probraných témat

Ve druhé části dotazníku pracovali studenti se stejnou škálou probraných témat a studenti měli označit tři z těch, která pro ně měla nejmenší přínos a která by z programu předmětu úplně vyřadili. Výsledky tohoto šetření jsou uvedeny v grafu 2.

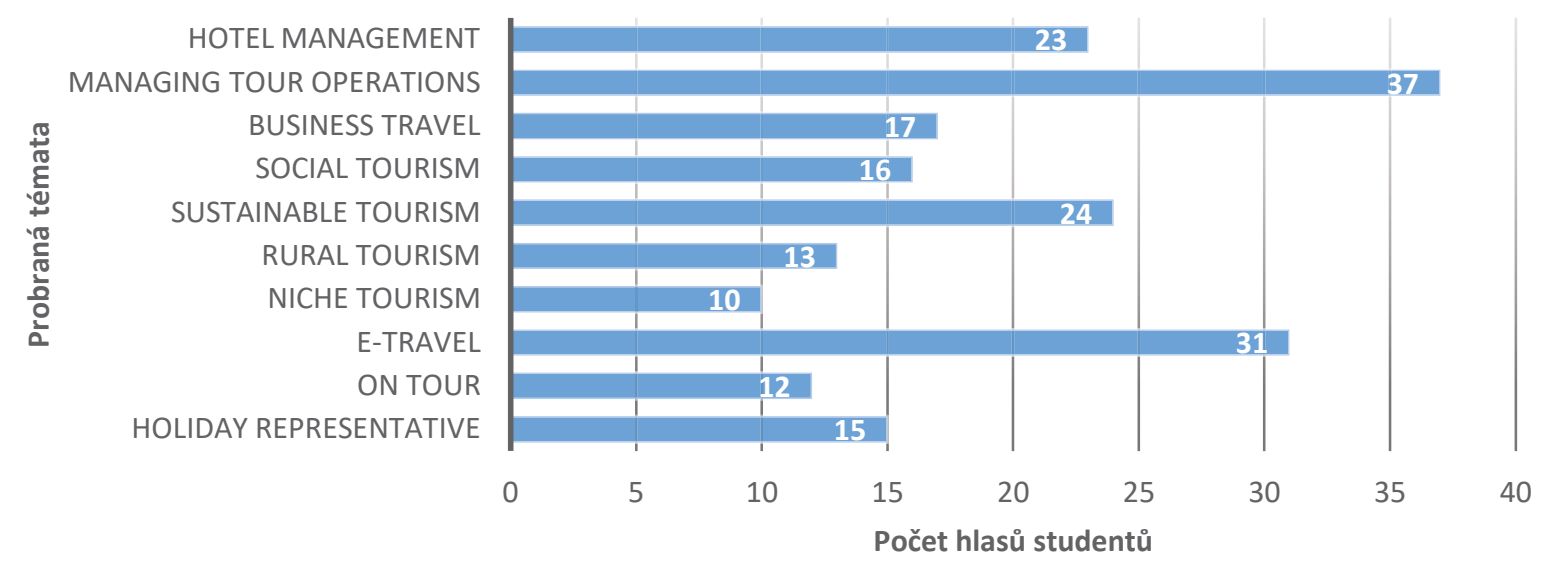

Graf 2: Graf neoblibenosti probraných témat

Ve třetí části dotazníku byla studentům z učebnic Tourism 2 a Tourism 3 předložena škála osmi nových témat, $\mathrm{z}$ nichž měli studenti vybrat tři témata, která shledali nejvíce zajímavými a kterými by v programu předmětu nahradili ta, která ve druhé části dotazníku vyškrtli. Výsledky tohoto šetření jsou uvedeny v grafu 3.

Ve čtvrté části dotazníku měli studenti možnost psát své komentáře týkající se především výukových a hodnotících metod. Tato část dotazníku přinesla velice pozitivní hodnocení. Studenti oceňovali především zajímavost a pestrost použitých 


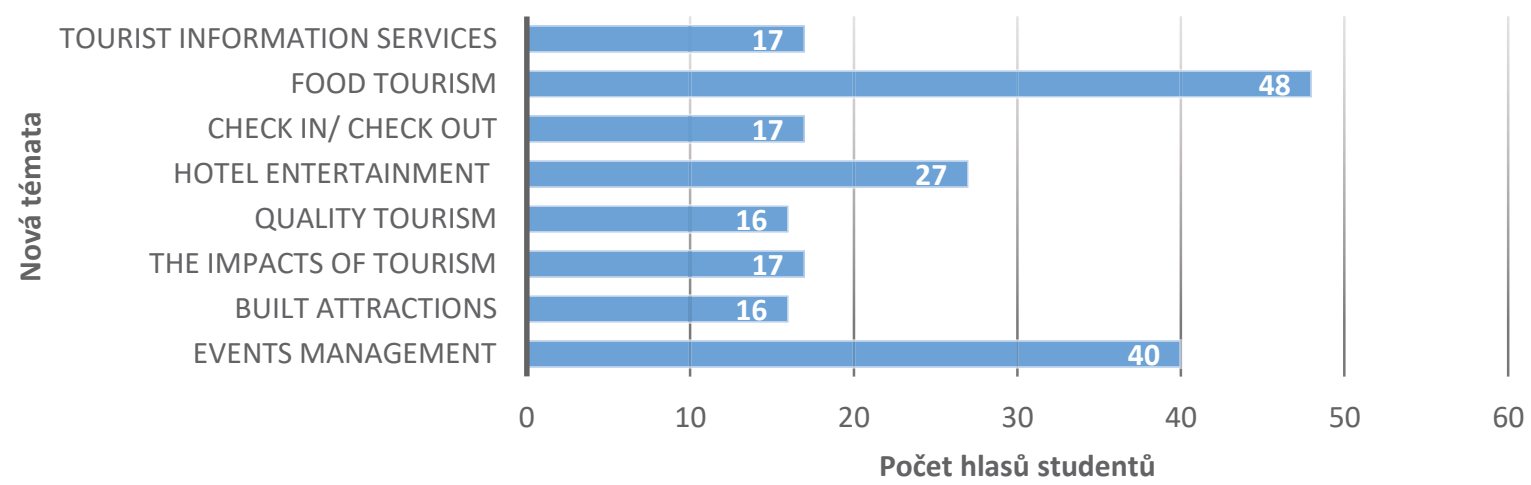

Graf 3: Graf výběru nových témat

aktivit a her $\mathrm{v}$ hodinách, srozumitelnost a přínos výuky, velmi příjemné třídní klima či hodnocení formou zmíněných studentských portfolií a prezentací.

Na základě výsledků dotazníkového šetření a na základě důkladného zvážení ze strany obou řešitelek byla následně provedena úprava studijního plánu. Původní témata e-Travel a Managing Tour Operations byla v programu předmětu nahrazena novými tématy Food Tourism a Events Management.

\section{Závěr}

Závěrem lze konstatovat, že řešitelky projektu naplnily jeho deklarovaný cíl, kterým bylo dosáhnout s přispěním nových učebních materiálů pozitivní změny obsahu předmětu UJP/EFT, a to v souladu jak se současným vývojem oboru cestovního ruchu, tak i v souladu s moderními metodami výuky anglického jazyka. Je zřejmé, že studenti dostali efektivním a zajímavým způsobem možnost získat praktické jazykové dovednosti potřebné pro komunikaci v obchodním a pracovním prostředí v oblasti cestovního ruchu.

\section{Literatura}

Berger, R. (2017). Sir Ken Robinson: Finding Market Pressures to Innovate Education. Forbes, 2017 (4). [online]. Dostupné z: https://www.forbes.com/sites/rodberger/2017/06/23/sir-ken-robinsonfinding-market-pressures-to-innovate-education/\#11ef3b961e77

ČAPEK, R. (2017). Líný učitel: Jak učit dobře a efektivně. Praha: Dr. Josef Raabe, s. r. o.

ČAPEK, R. (2015). Moderní didaktika. Praha: Grada.

Robinson, K. \& AronicA, L. (2016). Creative Schools. London: Penguin Books.

STRAuSS, V. (2015). Sir Kin Robinson has a lot to say about U.S. school reform.

The Washington Post, 2015 (4). [online]. Dostupné z: https://www.washingtonpost.com/news/answersheet/wp/2015/04/21/sir-ken-robinson-has-a-lot-to-say-about-u-s-school-reform-it-isnt-good/ ?utm_term=.83d6be6694e1 


\section{Autorky}

Mgr. Jitka Ramadanová, PhD., e-mail: ramadano@ujp.zcu.cz, Ústav jazykové př́pravy ZČU v Plzni.

Vystudovala obor Anglický jazyk a literatura a Ruský jazyk a literatura na FF UK v Praze v roce 1976. Od té doby působí jako vysokoškolský pedagog. V roce 2011 dokončila doktorské studium na FF ZČU v Plzni, obor Teorie a dějiny vědy a techniky. Absolvovala semestrální studijní pobyt na University of Lancaster a řadu pracovních stáží v UK. V současné době pracuje v Ústavu jazykové př́ípravy ZČU v Plzni, kde je garantem kurzů anglického jazyka Fakulty ekonomické a také garantem jazykové př́pravy studentů doktorského studia na Fakultě elektrotechnické a na Fakultě aplikovaných věd ZČU.

Ing. Petra Hromádková, e-mail: hromadkp@ujp.zcu.cz, Ústav jazykové přípravy ZČU v Plzni.

Vystudovala Fakultu ekonomickou ZČU v Plzni obor Cestovní ruch a obor Bankovnictví v rámci bakalářského studia a VŠE v Praze obor Finance a bankovnictví v rámci magisterského studia. Na Právnické fakultě UK v Praze absolvovala dvousemestrální studium Angličtina pro tlumočníky a překladatele. Na Pedagogické fakultě ZČU v Plzni vystudovala obor Učitelství 2 . stupně a aprobaci anglický jazyk. Působila jako lektorka angličtiny v jazykových školách. V současnosti pracuje v Ústavu jazykové př́pravy ZČU v Plzni, kde je mimo jiné garantem inovovaného kurzu Angličtina pro cestovní ruch. 